BEATA JEŻYŃSKA*

ORCID: 0000-0001-6753-5673

RadostaW PASTUSZKO**

ORCID: 0000-0002-2062-3622

\title{
Koncepcja rezerwatów biosfery UNESCO
}

1. Problematyka zrównoważonego rozwoju jest obecnie przedmiotem zainteresowania licznych gremiów naukowych, rządowych, społecznych, a dyskusja merytoryczna dotyczy wszystkich poziomów i rodzajów presji środowiskowych. Wywiera wpływ lokalny, regionalny i globalny. Każdy z nich ma swoją specyfikę, odmienny zakres oddziaływania, odrębne podstawy prawne i różnorodne instrumentarium prawne, organizacyjne i finansowe. Zrównoważony rozwój, jako przedmiot zainteresowania prawa rolnego, to przede wszystkim mechanizmy Wspólnej Polityki Rolnej Unii Europejskiej. Profesor Roman Budzinowski w swych licznych publikacjach zwracał uwagę na wielopłaszczyznowość i złożoność kształtowania stosunków prawnych w rolnictwie wynikających ze szczególnego uwarunkowania, że producent rolny jest jedocześnie korzystającym i chroniącym środowisko ${ }^{1}$. Wyważenie sprzecznych niekiedy potrzeb ochrony środowiska $\mathrm{z}$ ich gospodarczym wykorzystaniem stanowi istotny problem prawny o charakterze społecznym i gospodarczym ${ }^{2}$. Z tego względu za godne przedstawienia należy uznać

* Uniwersytet im. Marii Curie-Skłodowskiej w Lublinie.

** Uniwersytet im. Marii Curie-Skłodowskiej w Lublinie.

${ }^{1}$ R. Budzinowski, Status prawny rolnika jako przedsiębiorcy (zagadnienia wybrane), „Ruch Prawniczy, Ekonomiczny i Socjologiczny” 2002, nr 3, s. 111-120; idem, Przyrodniczo-techniczny czynnik rozwoju prawa rolnego, „Przegląd Prawa Rolnego” 2006, nr 1, s. 9-21; idem, Międzynarodowy czynnik rozwoju prawa rolnego, „Przegląd Prawa Rolnego” 2007, nr 2, s. 27-44; idem, Prawo rolne wobec wspótczesnych wyzwań, „Przegląd Prawa Rolnego” 2014, nr 2, s. 11-21.

${ }^{2}$ M.A. Król, Producent rolny jako podmiot korzystajacy ze środowiska, „Studia Iuridica Agraria” 2013, t. XI, s. 277-291; B. Jeżyńska, Wspótczesne funkcje gospodarstw rodzinnych. 
działania podejmowane przez UNESCO w zakresie tworzenia specyficznej platformy zrównoważonego współdziałania, jaką są rezerwaty biosfery. Stanowią one wyjątkowy przejaw realizacji zasady zrównoważonego rozwoju. Definiowane są jako „obszary ekosystemów lądowych i przybrzeżnych/ morskich lub ich kombinacji, które są uznane na arenie międzynarodowej w ramach Programu UNESCO dotyczącego Człowieka i Biosfery (MAB)"”.

Rezerwaty biosfery tworzą i zgłaszają do Sieci UNESCO rządy krajowe. Do uznania i wpisania do Sieci zgłoszonego obszaru muszą być spełnione określone minimalne kryteria oraz przestrzegane minimalne warunki. Pierwsza grupa obligatoryjnych wymagań dotyczy funkcji, jakie każdy z rezerwatów biosfery ma spełniać. Są to: 1) funkcja ochronna, polegająca na zachowaniu zasobów genetycznych, gatunków, ekosystemów i krajobrazów; 2) funkcja rozwojowa, polegająca na wspieraniu zrównoważonego rozwoju gospodarczego i ludzkiego; 3) funkcja wsparcia logistycznego, polegająca na wspieraniu projektów naukowych, demonstracyjnych, edukacji ekologicznej i szkoleń oraz badań i monitoringu związanych z lokalnymi, krajowymi i globalnymi zagadnieniami ochrony i zrównoważonego rozwoju. W najnowszych dokumentach dotyczących programu MAB wskazuje się na rosnące znaczenie społeczności lokalnych dla funkcjonowania i realizacji programów rozwoju rezerwatów biosfery jako 4) partycypacji społecznej w sferze decyzyjnej, co jest ich kolejną ważną funkcją.

Druga grupa wymagań minimalnych odnosi się do cech fizycznych obszarów o statusie rezerwatu biosfery. Pod względem fizycznym każdy rezerwat biosfery powinien zawierać trzy elementy: 1) jeden lub więcej obszarów rdzeniowych, które są chronionymi miejscami służącymi zachowaniu różnorodności biologicznej, monitorowaniu minimalnie zaburzonych ekosystemów oraz podejmowaniu badań nieniszczących i innych zastosowań o niewielkim wpływie na środowisko; 2) wyraźnie zidentyfikowaną strefę buforową, która zwykle otacza lub przylega do obszarów rdzeniowych i jest

Zagadnienia prawne, Opinie i Ekspertyzy OE - 214, Biuro Analiz i Dokumentacji Senatu, styczeń 2014; A. Niewiadomski, Rodzinne gospodarstwo rolne wobec ochrony środowiska w prawie polskim i europejskim, w: P. Litwiniuk (red.), Prawne mechanizmy wspierania i ochrony rolnictwa rodzinnego w Polsce i innych państwach Unii Europejskiej, Warszawa 2015, s. 141-152.

${ }^{3}$ Szerzej: M.I. Dyer, M.M. Holland, UNESCO's Man and the Biosphere Program, „BioScience" 1988, vol. 38(9), s. 635-641; N. Ishwaran, Science in intergovernmental environmental relations: 40 years of UNESCO's Man and the Biosphere (MAB) Programme and its future, ,Environmental Development" 2012, vol. 1(1), s. 91-101; M.G. Reed, The contributions of UNESCO Man and Biosphere Programme and biosphere reserves to the practice of sustainability science, „Sustainability Science” 2019, vol. 14(3), s. 809-821; N. Ishwaran, A. Persic, N.H. Tri, Concept and practice: The case of UNESCO biosphere reserves, „International Journal of Environment and Sustainable Development" 2008, vol. 7(2), s. 118-131. 
wykorzystywana do działań kooperacyjnych zgodnych ze zdrowymi praktykami ekologicznymi, w tym edukacji ekologicznej, rekreacji, ekoturystyki oraz badań stosowanych i podstawowych; 3) elastyczny obszar przejściowy, zwany też obszarem współpracy, który może obejmować różne działania rolnicze, osiedla i inne sposoby użytkowania i w którym społeczności lokalne, agencje zarządzające, naukowcy, organizacje pozarządowe, grupy kulturowe, interesy gospodarcze i inne zainteresowane strony współpracują w celu zarządzania i zrównoważonego rozwoju zasobów obszaru. Pierwotnie wskazane obszary zaplanowane były jako układ koncentrycznych pierścieni, ale praktyka pokazała, że strefy są wyodrębniane na wiele sposobów, by sprostać lokalnym potrzebom i warunkom. W rzeczywistości jednym z największych atutów koncepcji rezerwatu biosfery jest elastyczność i kreatywność, z jaką jest ona realizowana.

2. Koncepcja rezerwatów biosfery ma wieloletnią historię zapoczątkowaną Programem UNESCO „Człowiek i Biosfera” (Man and Biosphere - MAB). Przeszła też wyraźną ewolucję.

2.1. Program „Człowiek i Biosfera” został zainicjowany w 1968 r. przez UNESCO na Międzynarodowej Konferencji o Ochronie i Racjonalnym Użytkowaniu Zasobów Biosfery. Określany był jako program interdyscyplinarnych badań relacji między ludźmi a ich środowiskiem. Zmierzał do wypracowania harmonijnego rozwoju socjalnego i ekonomicznego z utrzymaniem miejscowych wartości kulturowych i ochroną naturalnego środowiska i lokalnych ekosystemów ${ }^{4}$. Rezerwaty biosfery miały ów harmonijny rozwój promować i chronić. Koncepcja zakładała pokrycie siecią rezerwatów biosfery głównych biomów, regionów oraz stref geograficznych. A zatem ich cechą charakterystyczną jest spójny rozwój typowych dla danego obszaru ekosystemów. Na kolejnych spotkaniach Rady Koordynacyjnej MAB doprecyzowano cel i sposób powoływania rezerwatów biosfery MAB. Ostateczna koncepcja została opracowana przez grupę zadaniową programu UNESCO „Człowiek i Biosfera” w 1974 r., a w 1976 r. powołano Sieć Rezerwatów Biosfery w celu osiągnięcia trwałej równowagi między zachowaniem różnorodności biologicznej, promowaniem rozwoju gospodarczego i utrzymaniem związanych z nimi wartości kulturowych. Rezerwaty biosfery są obszarami, gdzie ten cel jest testowany, udoskonalany, demonstrowany i wdrażany ${ }^{5}$.

${ }^{4}$ M. Hadley, A practical ecology: The man and the biosphere (MAB) programme, w: P. Petitjean, V. Zharov, G. Glaser, J. Richardson, B. de Padirac, G. Archibald (red.), Sixty Years of Science at UNESCO 1945-2005, Paris 2006, s. 260-296.

${ }^{5}$ L.K. Caldwell, International Environmental Policy, Durham, NC 1996, s. 375-379. 
2.2. Kolejne działania formalne podjęte zostały na początku lat 80 . XX wieku. W 1983 r. UNESCO i Program Środowiskowy Organizacji Narodów Zjednoczonych (UNEP) zwołały Pierwszy Międzynarodowy Kongres Rezerwatów Biosfery w Mińsku, we współpracy z Organizacją Narodów Zjednoczonych do spraw Wyżywienia i Rolnictwa (FAO) i Światową Unią Ochrony Przyrody (IUCN). Działania podjęte na kongresie dały początek opracowaniu i przyjęciu w 1984 r. Planu Działania na rzecz rezerwatów biosfery, który został formalnie zatwierdzony przez Konferencję Generalną UNESCO oraz Radę Zarządzającą UNEP. Była to propozycja intensywnego rozwoju rezerwatów biosfery, zarówno pod względem ich liczby, jak i zajmowanej powierzchni, a także programów naukowych realizowanych na obszarach rezerwatów biosfery.

2.3. Chociaż znaczna część Planu Działania z 1984 r. pozostaje aktualna do dziś, to kontekst, w którym funkcjonują rezerwaty biosfery, uległ znacznej zmianie. W związku z tym Rada Wykonawcza UNESCO postanowiła w 1991 r. powołać Komitet Doradczy ds. Rezerwatów Biosfery, który uznał za konieczne przeprowadzenie oceny skuteczności Planu Działania z 1984 r. oraz opracowanie strategii rezerwatów biosfery XXI wieku. Efekty prac Komitetu zostały zaprezentowane podczas Konferencji Narodów Zjednoczonych na temat Środowiska i Rozwoju (UNCED), w szczególności Konwencja o różnorodności biologicznej, podpisana na „Szczycie Ziemi” w Rio de Janeiro w czerwcu 1992 r. Założony w konwencji cel, jakim jest ochrona różnorodności biologicznej przy zrównoważonym użytkowaniu jej składników oraz uczciwy i sprawiedliwy podział korzyści wynikających z wykorzystania zasobów genetycznych, w pełni odpowiada celom realizowanym przez rezerwaty biosfery UNESCO. Związek między ochroną różnorodności biologicznej a potrzebami rozwojowymi społeczności lokalnych został uznany za kluczową cechę skutecznego zarządzania większością parków narodowych, rezerwatów przyrody i innych obszarów chronionych.

2.4. Zgodnie z rezolucją 27/C/2.3 Konferencji Generalnej UNESCO w Sewilli w dniach 20-25 marca 1995 r. odbyła się Międzynarodowa Konferencja na temat Rezerwatów Biosfery. Prace konferencji przebiegały dwutorowo. Po pierwsze, dokonano podsumowania dotychczasowych doświadczeń w realizacji innowacyjnej koncepcji rezerwatu biosfery, a po drugie, sformułowano nowe założenia jej podstawowych funkcji: ochronnej, rozwojowej i wsparcia logistycznego. Przyjęto, że rezerwaty biosfery powinny chronić i generować wartości przyrodnicze i kulturowe przez zarządzanie, które jest 
naukowo poprawne, kulturowo twórcze i operacyjnie zrównoważone. Światowa Sieć Rezerwatów Biosfery (WNBR), realizowana na gruncie Strategii Sewilskiej, uznawana jest za narzędzie integrujące, które może przyczynić się do stworzenia większej solidarności pomiędzy ludźmi i narodami świata. Na konferencji opracowano także Ramowy Statut dla rezerwatów biosfery należących do Sieci UNESCO ${ }^{6}$.

2.5. Kolejne działania podjęto w 2008 r. na Trzecim Światowym Kongresie Rezerwatów Biosfery, który odbył się w Madrycie. Przyjęto wówczas Madrycki Plan Działań na rzecz Rezerwatów Biosfery ${ }^{7}$, który uwzględniał założenia Strategii Sewilskiej, ale także zakładał takie zwiększenie obszarów i znaczenia rezerwatów biosfery, by uzyskać na arenie międzynarodowej status wiodącej formy działań na rzecz zrównoważonego rozwoju XXI wieku. MAB określił działania, cele i wskaźniki sukcesu, partnerstwa i inne strategie wdrażania, a także ramy oceny Sieci rezerwatów na lata 2008-2013.

2.6. Kolejny okres programowania został opracowany na konferencji w Limie, w czasie której przyjęto trzy dokumenty: Strategię MAB na lata 2015-2025, Plan Działania z Limy oraz Deklarację z Limy ${ }^{8}$. Dokumenty zawierają kompleksowy zestaw działań mających na celu zapewnienie skutecznej realizacji Strategii MAB 2015-2025, przyjętej przez MAB ICC na 27. sesji UNESCO ${ }^{9}$ i zatwierdzonej przez Konferencję Generalną UNESCO na jej 38. sesji ${ }^{10}$. Ogłoszono w niej: „Naszą wizją jest świat, w którym ludzie są świadomi swojej wspólnej przyszłości i interakcji z naszą planetą oraz działają wspólnie i odpowiedzialnie, aby budować dobrze prosperujące społeczeństwa w harmonii w biosferze. Program MAB i jego Światowa Sieć Rezerwatów Biosfery (WNBR) służą tej wizji w obrębie rezerwatów biosfery i poza nimi”. Kluczowe według Strategii MAB są lata 2015-2025. Została ona opracowana zgodnie ze średniookresową Strategią UNESCO na lata 2014-2021, Strategią Sewilską i Ramami Statutowymi WNBR, z uwzględnieniem zaleceń wynikających z końcowej oceny MAB. Cele i obszary

\footnotetext{
${ }^{6}$ Biosphere reserves: the Seville Strategy and the statutory framework of the world network, https://unesdoc.unesco.org/ark:/48223/pf0000103849 [dostęp: 13.10.2021].

7 Madrid Action Plan for Biosphere Reserves (2008-2013), SC.2008/WS/36, SC.2010/ $\mathrm{WS} / 22$

${ }^{8}$ A New roadmap for the Man and the Biosphere (MAB) Programme and its World Network of Biosphere Reserves, https://unesdoc.unesco.org/ark:/48223/pf0000247418 [dostęp: 7.05.2021].

${ }^{9}$ Paryż, 8-12 czerwca $2015 \mathrm{r}$.

${ }^{10}$ Paryż, 3-18 listopada $2015 \mathrm{r}$.
} 
działania określone w Strategii MAB będą wdrażane przez powiązany Plan Działań MAB, a ich realizacja będzie oceniana za pomocą Ram Ewaluacyjnych. Cele strategiczne MAB na lata 2015-2025 wywodzą się z trzech funkcji rezerwatów biosfery określonych w Ramach Ustawowych WNBR oraz kluczowego globalnego wyzwania, jakim są zmiany klimatyczne, określone w Madryckim Planie Działań na rzecz Rezerwatów Biosfery.

Cel strategiczny 1. Ochrona bioróżnorodności, przywracanie i wzmacnianie usług ekosystemowych oraz wspieranie zrównoważonego wykorzystania zasobów naturalnych. W uzasadnieniu dokonanego wyboru autorzy koncepcji stwierdzili, że utrata bioróżnorodności skutkuje redukcją usług ekosystemowych, stwarza bezpośrednie zagrożenie dla dobrostanu człowieka i jest ważnym wskaźnikiem niezrównoważonego systemu. Utrata i fragmentacja siedlisk spowodowana presją antropocentryczną, a zwłaszcza niezrównoważonymi wzorcami konsumpcji i produkcji, jest główną przyczyną zmniejszania bioróżnorodności na całym świecie. Obecna, nieznana wcześniej skala eksploatacji zasobów naturalnych wymaga lepszego zarządzania nimi i wykorzystania ich ${ }^{11}$.

Cel strategiczny 2. Przyczynianie się do budowania zrównoważonych, zdrowych i sprawiedliwych społeczeństw, gospodarek i prosperujących osiedli ludzkich w harmonii z biosferą. Podstawą wyboru tego celu było twierdzenie, że ludność na świecie w coraz większym stopniu koncentruje się w szybko rozwijających się obszarach miejskich o różnej wielkości, co prowadzi do nadmiernej eksploatacji i niezrównoważonego wykorzystania ograniczonych zasobów naturalnych, przyspiesza zanieczyszczenie środowiska i degradacji oraz ma istotny wpływ na ludzkie samopoczucie. Zdrowe, sprawiedliwe społeczeństwa i gospodarki oraz osiedla ludzkie są głównym celem dążenia do długoterminowej stabilności i rozwoju społecznego. Osiągnięcie tego celu wymaga dogłębnej znajomości dziedzictwa przyrodniczego i kulturowego, realiów społecznogospodarczych oraz innowacyjnego podejścia do zwiększania odporności na zmiany środowiskowe. Sieć Rezerwatów Biosfery MAB jest wyjątkowo dobrze przygotowana do realizacji celu, jakim jest uzyskanie dobrze prosperujących gospodarek i zrównoważonych społeczeństw, nie tylko przez poszczególne państwa członkowskie, ale także przez transgraniczne rezerwaty biosfery. Transgraniczne rezerwaty biosfery dają możliwości współpracy, sprzyjają harmonijnemu współistnieniu ludzi, ludzi i przyrody oraz promują

${ }^{11}$ Por. rozważania uwzględniające aspekt produkcji rolnej i żywnościowej: R. Lal, Enhancing ecosystem services with no-till, „Renewable Agriculture and Food Systems” 2013, vol. 28(2), s. $102-114$. 
kulturę pokoju w kwestii korzystania ze wspólnych zasobów naturalnych i czerpania z nich korzyści przez wszystkich zainteresowanych.

Cel strategiczny 3. Ułatwienie nauki o bioróżnorodności i zrównoważonym rozwoju, edukacji na rzecz zrównoważonego rozwoju (ESD) i budowania potencjału. Nauka o zrównoważonym rozwoju - zdaniem autorów koncepcji - to zintegrowane podejście do rozwiązywania problemów, które w transdyscyplinarny sposób czerpie z dostępnej wiedzy naukowej, tradycyjnej i miejscowej, by identyfikować, rozumieć i rozwiązywać obecne i przyszłe problemy gospodarcze, środowiskowe, etyczne i społeczne związane ze zrównoważonym rozwojem ${ }^{12}$. Na tym poziomie rezerwat biosfery wymaga współpracy między wszystkimi zainteresowanymi stronami, w tym naukowcami, politykami, twórcami, członkami społeczności lokalnych i zaangażowanymi przedstawicielami sektora prywatnego. ESD promuje włączenie najważniejszych zagadnień zrównoważonego rozwoju do nauczania, aby motywować i wzmacniać uczniów do zmiany ich zachowania przez nabywanie nowych umiejętności, kompetencji i wartości oraz do podejmowania działań na rzecz zrównoważonego rozwoju. Rezerwaty biosfery mogą mieć istotne znaczenie w operacjonalizacji i wykorzystywaniu nauki o zrównoważonym rozwoju na poziomie lokalnym i regionalnym w celu budowania wiedzy naukowej, identyfikowania najlepszych praktyk i wzmacniania powiązań między nauką, polityką oraz edukacją i szkoleniem na rzecz zrównoważonego rozwoju ${ }^{13}$.

Cel strategiczny 4. Wspieranie łagodzenia i adaptacji do zmian klimatu oraz innych aspektów globalnych zmian środowiskowy ch. Zgodnie z piątym Raportem Oceniającym Międzyrządowego Zespołu ds. Zmian Klimatu (IPCC) ocieplenie systemu klimatycznego jest faktem. Wiele obserwowanych od lat 50. XX wieku zmian pojawiło się pierwszy raz od tysiącleci. Konkretne walory i możliwości rezerwatów biosfery w odniesieniu do zmian klimatu zostały uwzględnione w Madryckim Planie Działań na rzecz Rezerwatów Biosfery (2008-2013) oraz Deklaracji Drezdeńskiej w sprawie Rezerwatów Biosfery i Zmian Klimatu (2011). Kładą one nacisk na możliwości Programu MAB i rezerwatów biosfery w zakresie łagodzenia skutków zmian klimatu i dostosowywania się do nich oraz skutecznego włączania ich

${ }^{12}$ Por. H. Kopnina, Education for the future? Critical evaluation of education for sustainable development goals, „The Journal of Environmental Education” 2020, vol. 51(4), s. 280-291; L. López, M.C. Rubio, D. Rodríguez, The role of scientists at the human-nature interface on MaB protected areas, „Cuadernos Geográficos” 2021, vol. 60(1), s. 263-278.

${ }_{13}$ B. Jeżyńska, Proekologiczne instrumenty wsparcia zrównoważonego rozwoju obszarów wiejskich, „Studia Iuridica Agraria” 2012, t. X, s. 251-264. 
w krajowe i międzynarodowe strategie i polityki klimatyczne ${ }^{14}$. Wymaga to uwzględnienia i monitorowania interakcji między zmianą klimatu a innymi aspektami globalnej zmiany środowiska, takimi jak: utrata bioróżnorodności, urbanizacja, pustynnienie, degradacja zasobów ziemi i wody oraz zubożenie warstwy ozonowej w stratosferze. Plan Działania z Limy jest przedstawiony jako matryca, ustrukturyzowana zgodnie ze strategicznymi obszarami działania Strategii MAB 2015-2025. Zawiera docelowe działania i rezultaty, które mają przyczynić się do realizacji celów strategicznych zawartych w Strategii. Określa również podmioty ponoszące główną odpowiedzialność za wdrożenie wraz z zakresem czasowym i wskaźnikami efektywności. Wykorzystując Strategię MAB 2015-2025 oraz Plan Działań z Limy 2016-2025 jako kluczowe punkty odniesienia, Komitety Krajowe MAB i sieci MAB są zachęcane do przygotowania własnych strategii i planów działania. Powinny one opierać się na krajowych i regionalnych realiach i imperatywach oraz przyczyniać się zarówno do rozwiązania tych problemów, jak i do wdrożenia Planu Działania z Limy na poziomie globalnym ${ }^{15}$.

Podsumowując rozważania, można stwierdzić, że UNESCO od lat działa na rzecz ochrony środowiska, ograniczania utraty bioróżnorodności planety, łącząc to z rozwojem człowieka. Prowadzi takie programy, jak: Międzynarodowy Program Hydrologiczny (International Hydrological Programme, IHP), Międzynarodowy Program Nauk o Ziemi (International Geoscience Programme, IGCP), Międzynarodowa Komisja Oceanograficzna (Intergovernmental Oceanographic Commission, IOC) oraz Program Zarządzania Transformacją Społeczną (Management of Social Transformations, MOST) czy Globalny Program Działań (GAP) w sprawie Edukacji dla Zrównoważonego Rozwoju (Education for Sustainable Development, ESD). We wszystkich wskazanych aktywnościach mogą, a nawet powinny uczestniczyć rezerwaty biosfery. Program UNESCO „Człowiek i Biosfera” realizuje najszerzej ujęte cele zrównoważonego rozwoju w ramach rezerwatów biosfery, łącząc aspekty lokalne, regionalne i globalne w spójną całość społeczną, gospodarczą, kulturową i środowiskową. Należy podkreślić przenikliwość badawczą Profesora Romana Budzinowskiego, który właśnie na te związki - w kontekście działalności rolniczej - wielokrotnie zwracał uwagę.

\footnotetext{
${ }^{14}$ Szerzej: A. Meggle, Biosphere reserves, real-life observatories of climate change, draft UNESCO MAB report based on a 2015 survey, Paris 2017.

${ }^{15}$ G. Köck, A. Arnberger, L. Möller, Agenda 2030 und Lima-Aktionsplan-Anpassung der Biosphere Reserves für die Zukunft, „Biosphäre 4.0”, Berlin - Heidelberg 2020, s. 61-83.
} 


\section{BIBLIOGRAFIA}

Budzinowski R. (2002), Status prawny rolnika jako przedsiębiorcy (zagadnienia wybrane), „Ruch Prawniczy, Ekonomiczny i Socjologiczny” nr 3.

Budzinowski R. (2006), Przyrodniczo-techniczny czynnik rozwoju prawa rolnego, „Przegląd Prawa Rolnego" nr 1.

Budzinowski R. (2007), Międzynarodowy czynnik rozwoju prawa rolnego, „Przegląd Prawa Rolnego" nr 2.

Budzinowski R. (2014), Prawo rolne wobec współczesnych wyzwań, „Przegląd Prawa Rolnego" nr 2.

Caldwell L.K. (1996), International Environmental Policy, Duke University Press.

Dyer M.I., Holland M.M. (1988), UNESCO's Man and the Biosphere Program, „BioScience” vol. 38(9).

Hadley M. (2006), A practical ecology: the man and the biosphere (MAB) programme, w: P. Petitjean, V. Zharov, G. Glaser, J. Richardson, B. de Padirac, G. Archibald (red.), Sixty Years of Science at UNESCO 1945-2005, Paris.

Ishwaran N. (2012), Science in intergovernmental environmental relations: 40 years of UNESCO's Man and the Biosphere (MAB) Programme and its future, „Environmental Development" vol. 1(1).

Ishwaran N., Persic A., Tri N.H. (2008), Concept and practice: the case of UNESCO biosphere reserves, „International Journal of Environment and Sustainable Development" vol. 7(2).

Jeżyńska B. (2012), Proekologiczne instrumenty wsparcia zrównoważonego rozwoju obszarów wiejskich, „Studia Iuridica Agraria” t. X.

Jeżyńska B. (2014), Wspótczesne funkcje gospodarstw rodzinnych. Zagadnienia prawne, Opinie i Ekspertyzy OE - 214, Biuro Analiz i Dokumentacji Senatu.

Köck G., Arnberger A., Möller L. (2020), Agenda 2030 und Lima-Aktionsplan-Anpassung der Biosphere Reserves für die Zukunft, „Biosphäre 4.0”, Berlin - Heidelberg.

Kopnina H. (2020), Education for the future? Critical evaluation of education for sustainable development goals, „The Journal of Environmental Education” vol. 51(4).

Król M. A. (2013), Producent rolny jako podmiot korzystający ze środowiska, „Studia Iuridica Agraria" t. XI.

Lal R. (2013), Enhancing ecosystem services with no-till, ,,Renewable Agriculture and Food Systems" vol. 28(2).

López L., Rubio M.C., Rodríguez D. (2021), The role of scientists at the human-nature interface on MaB protected areas, „Cuadernos Geográficos” vol. 60(1).

Meggle A. (2016), Biosphere reserves, real-life observatories of climate change, draft UNESCO MAB report based on a 2015 survey, Paris 2017.

Niewiadomski A. (2015), Rodzinne gospodarstwo rolne wobec ochrony środowiska w prawie polskim i europejskim, w: P. Litwiniuk (red.), Prawne mechanizmy wspierania i ochrony rolnictwa rodzinnego w Polsce i innych państwach Unii Europejskiej, Warszawa.

Reed M.G. (2019), The contributions of UNESCO Man and Biosphere Programme and biosphere reserves to the practice of sustainability science, „Sustainability Science” vol. 14(3). 


\title{
THE UNESCO CONCEPT OF BIOSPHERE RESERVES
}

\author{
Summary
}

Sustainable development and problems related to it are currently the subject of interest of numerous scientific, governmental and social bodies, and the discussion that is going on concerns all levels and types of environmental pressures. Therefore, the activities undertaken by UNESCO that aim at creating a platform for sustainable interaction in the form of biosphere reserves should be considered as worthy of presentation here. They constitute an exceptional manifestation of the implementation of the sustainable development principle in practice.

Keywords: biosphere, agricultural activity, sustainable development

\section{LA CONCEZIONE DI RISERVA DI BIOSFERA DELL'UNESCO}

\section{Riassunto}

Al giorno d'oggi lo sviluppo sostenibile costituisce un argomento d'interesse in numerose sedi scientifiche, governative, sociali, con le discussioni coerenti con temi che riguardano tutti i livelli e tutti i tipi di pressione ambientale. Per questo motivo, degne di nota sono le attività intraprese dall'UNESCO per creare una piattaforma specifica per la cooperazione sostenibile, vale a dire le riserve di biosfera, le quali sono un eccezionale esempio del principio di sviluppo sostenibile messo in pratica.

Parole chiave: biosfera, attività agricola, sviluppo sostenibile 